\title{
Commentary Fat tissue and adiponectin: new players in critical care? Maciej Owecki
}

\author{
Department of Endocrinology, Metabolism and Internal Medicine, University of Medical Sciences in Poznań, ul. Przybyszewskiego 49, \\ 60-355 Poznań, Poland
}

Corresponding author: Maciej Owecki, mowecki@ump.edu.pl

Published: 5 August 2009

This article is online at http://ccforum.com/content/13/4/174

(c) 2009 BioMed Central Ltd

Critical Care 2009, 13:174 (doi:10.1186/cc7974)

See related research by Venkatesh et al., http://ccforum.com/content/13/4/R105

\begin{abstract}
Historically, adipose tissue was thought to be a passive tissue that stores energy and protects the body from temperature and injury. In contrast to this concept, it is now evident that adipose tissue is an active endocrine organ secreting many kinds of adipocytokines, including adiponectin. Presumably, adipose tissue and its products may have some impact on numerous pathways of response to trauma, sepsis and stress. The discussion on a plausible role of adiponectin in critical illness has been raised by the fact of finding hypoadiponectinemia in critically ill patients. The nature of this phenomenon, however, remains to be elucidated, and noteworthy clinical studies should prompt further efforts in basic research to explain the mechanisms beyond the clinical observation of low adiponectin levels in humans with severe illness.
\end{abstract}

In the current issue of Critical Care, Venkatesh and colleagues present a novel study on adiponectin in critical illness [1]. This article, along with the concept of adipose tissue and adipocytokines being involved in the mechanisms of critical illness, requires some commentary.

Historically, adipose tissue was thought to be an inert tissue that stores energy and protects the body from temperature and injury. In contrast to this concept, it is now evident that adipose tissue is an active endocrine organ secreting many kinds of adipocytokines - such as adiponectin, leptin, IL-6, and TNF $\alpha$ - that may affect metabolism, body weight regulation, and glucose and lipid homeostasis [2]. Produced exclusively in the adipose tissue, adiponectin is the most abundant adipocytokine and circulates in the blood at high concentrations, accounting for approximately $0.01 \%$ of the total plasma protein [3-5]. Studies in rodents demonstrate a role for adiponectin in obesity and insulin resistance $[6,7]$. In humans, reduced serum levels of adiponectin in obese subjects compared with nonobese subjects and negative correlations between adiponectin and body mass index (BMI) have, and have not, been reported [8-10]. Furthermore, serum concentrations of adiponectin have been found to be inversely correlated with insulin resistance in both nonobese and obese subjects and in patients with type 2 diabetes mellitus [11-13].

In spite of numerous clinical studies on adiponectin, however, its exact role in metabolism is unclear and remains to be elucidated, along with the as yet unsolved adiponectin paradox: a decreased concentration of adiponectin in obesity seems paradoxical, since fat tissue is the only known source of this protein. In viuew of that, the paper by Venkatesh and colleagues broadens knowledge of the subject and links the function of adipose tissue to the general defense against critical illness [1]. The authors' suggestion that adiponectin may play a part in the inflammatory response in patients with critical illness is interesting, but it should be considered bearing in mind some limitations of the study. Perhaps the major limitation is the lack of data on patients' BMI. Associations between low and high BMI and mortality are well known, as are the correlations between BMl and adiponectin. Different BMl values between groups could consequently have influenced the adiponectin results. Under these circumstances, the final results should be interpreted cautiously.

Furthermore, the associations between serum cortisol and adiponectin in critical care patients demonstrated in this study also require comment. The high standard deviation for cortisol might have been caused by adrenal insufficiency in several patients with very low cortisol levels. In this setting, the group is not homogeneous with respect to adrenal response to stress, and consequently the overall statistical result may be confusing. Still, the authors have raised an interesting problem regarding the link between adrenal function and adipose tissue metabolism in critical illness. An increased secretion of glucocorticoids by the adrenal gland is

$\mathrm{BMI}=$ body mass index; IL= interleukin; TNF = tumor necrosis factor. 
a well-known defense mechanism against hypotension and stress, whereas a decreased cortisol concentration is associated with a worse prognosis. On the basis of this article, therefore, one can propose the hypothesis that a decreased adrenal response presumably inhibits protective adiponectin secretion, thus deteriorating the overall clinical condition. Obviously, in face of the above-mentioned study limitations, this tempting hypothesis requires further research.

Although based on a preliminary study only, the idea shown by Venkatesh and colleagues generates new hypotheses meaning we should have a rethink of the role of fat tissue in the critical state in humans. Obviously the authors did not investigate the mechanism of decreased adiponectin in critical illness, as it was not the aim of their study. However, the following fact is now evident: being a complicated organ and being spread throughout the body hormone-producing and cytokine-producing machinery, adipose tissue cannot stand passively by in the face of severe threat to life, and is involved in numerous inflammatory responses including production of adipocytokines, TNFs, and metabolites of fat catabolism. The nature of these responses remains to be elucidated, however, and noteworthy clinical studies should prompt further efforts in basic research to explain the mechanisms beyond clinical observations.

\section{Competing interests}

The author declares that they have no competing interests.

\section{References}

1. Venkatesh B, Hickman I, Nisbett J, Cohen J, Prins J: Changes in serum adiponectin concentrations in critical illness: a preliminary investigation. Crit Care 2009, 13:R105.

2. Friedman JM: Obesity in the new millennium. Nature 2000, 404: 632-634.

3. Scherer PE, Williams S, Fogliano M, Baldini G, Lodish HF: A novel serum protein similar to $\mathrm{C} 1 \mathrm{q}$, produced exclusively in adipocytes. J Biol Chem 1995, 270:26746-26749.

4. Fruebis J, Tsao TS, Javorschi S, Ebbets-Reed D, Erickson MR, Yen FT, Bihain BE, Lodish HF: Proteolytic cleavage product of 30-kDa adipocyte complement-related protein increases fatty acid oxidation in muscle and causes weight loss in mice. Proc Natl Acad Sci USA 2001, 98:2005-2010.

5. Berg AH, Combs TP, Scherer PE: ACRP30/adiponectin: an adipokine regulating glucose and lipid metabolism. Trends Endocrinol Metab 2002, 13:84-89.

6. Kubota N, Terauchi Y, Yamauchi T, Kubota T, Moroi M, Matsui J, Eto K, Yamashita T, Kamon J, Satoh H, Yano W, Froguel P, Nagai R, Kimura S, Kadowaki T, Noda T: Disruption of adiponectin causes insulin resistance and neointimal formation. J Biol Chem 2002, 277:25863-25866.

7. Berg $A H$, Combs TP, Du X, Brownlee M, Scherer PE: The adipocyte-secreted protein Acrp30 enhances hepatic insulin action. Nat Med 2001, 7:947-953.

8. Arita Y, Kihara S, Ouchi N, Takahashi M, Maeda K, Miyagawa J, Hotta K, Shimomura I, Nakamura T, Miyaoka K, Kuriyama H, Nishida M, Yamashita S, Okubo K, Matsubara K, Muraguchi M, Ohmoto $Y$, Funahashi T, Matsuzawa Y: Paradoxical decrease of an adipose-specific protein, adiponectin, in obesity. Biochem Biophys Res Commun 1999, 257:79-83.

9. Staiger $\mathrm{H}$, Tschritter O, Machann J, Thamer C, Fritsche A, Maerker E, Schick F, Haring HU, Stumvoll M: Relationship of serum adiponectin and leptin concentrations with body fat distribution in humans. Obes Res 2003, 11:368-372.

10. Owecki M, Miczke A, Pupek-Musialik D, Bryl W, Cymerys M, Nikisch E, Sowiński J: Circulating serum adiponectin concen- trations do not differ between obese and non-obese Caucasians and are unrelated to insulin sensitivity. Horm Metab Res 2007, 39:25-30.

11. Pellme F, Smith U, Funahashi T, Matsuzawa $Y$, Brekke $H$, Wiklund $\mathrm{O}$, Taskinen MR, Jansson PA: Circulating adiponectin levels are reduced in nonobese but insulin-resistant first-degree relatives of type 2 diabetic patients. Diabetes 2003, 52:1182-1186.

12. Weyer C, Funahashi T, Tanaka S, Hotta K, Matsuzawa Y, Pratley $\mathrm{RE}$, Tataranni PA: Hypoadiponectinemia in obesity and type 2 diabetes: close association with insulin resistance and hyperinsulinemia. J Clin Endocrinol Metab 2001, 86:1930-1935.

13. Kern PA, Di Gregorio GB, Lu T, Rassouli N, Ranganathan G: Adiponectin expression from human adipose tissue: relation to obesity, insulin resistance, and tumor necrosis factor expression. Diabetes 2003, 52:1779-1785. 